\title{
Morphology-directed synthesis of $\mathrm{LiFePO}_{4}$ and $\mathrm{LiCoPO}_{4}$ from nanostructured $\mathrm{Li}_{1+2 \mathrm{x}} \mathrm{PO}_{3+\mathrm{x}}$
}

\author{
Hany El-Shinawi, ${ }^{*}$ Edmund J. Cussen $† \ddagger$ and Serena A. Corr $\neq \dagger,{ }^{*}$ \\ ‡ Department of Chemical and Biological Engineering, University of Sheffield, Sir Robert Hadfield \\ Building, Sheffield, S1 3JD, UK. \\ † Department of Materials Science and Engineering, University of Sheffield, Sir Robert Hadfield \\ Building, Sheffield, S1 3JD, UK.
}

\section{Supplementary information}

\section{Experimental section:}

Synthesis of $\mathrm{LiPO}_{3}$-type phase

Phosphorus pentasulfide $\left(\mathrm{P}_{2} \mathrm{~S}_{5}\right)$ and lithium tert-butoxide were purchased from Sigma-Aldrich and used as-received as starting materials. The two materials were mixed in 1:2 mole ratio in tetraglyme (Aldrich) and heated in an argon atmosphere to $130{ }^{\circ} \mathrm{C}$ for few minutes. $5 \mathrm{ml}$ of the resulting clear solution was then heated in a sealed microwave tube for $20 \mathrm{~min}$ at $200^{\circ} \mathrm{C}$ using a CEM Discover SP microwave synthesizer $(2.45 \mathrm{GHz})$. The resulting product was washed thoroughly with THF $(3 \times 3 \mathrm{ml})$ and finally dried in air at $150^{\circ} \mathrm{C}$ for $2 \mathrm{~h}$.

Synthesis of $\mathrm{LiMPO}_{4}$ and $\mathrm{LiMPO}_{4} / \mathrm{C}(\mathrm{M}=\mathrm{Fe}$ and $\mathrm{Co})$

Stoichiometric amounts of the as-synthesized $\mathrm{LiPO}_{3}$-type phase and either $\mathrm{FeCl}_{2}$ or $\mathrm{CoCl}_{2}$ (1:1 molar ratio), were sonicated in THF for $30 \mathrm{~min}$. The solvent was then evaporated slowly at $70-80^{\circ} \mathrm{C}$, followed by a final six-hour calcination steps at $500{ }^{\circ} \mathrm{C}$ under $5 \% \mathrm{H}_{2} / \mathrm{Ar}$ (for $\mathrm{LiFePO}_{4}$ ) or $600{ }^{\circ} \mathrm{C}$ under $\mathrm{Ar}$ (for LiCoPO${ }_{4}$ ). To prepare carbon-free phases, a pre-calcination step in air at $300{ }^{\circ} \mathrm{C}$ for two hours was employed prior to the final calcination steps.

\section{Characterization:}

XRD patterns were collected using a PANalytical X'Pert PRO diffractometer in reflection mode using Cu-K $\alpha$ radiation. Rietveld fits to XRD data were performed using the GSAS and EXPGUI suite of programmes. SEM studies were performed using a Zeiss Sigma field emission scanning electron microscope and TEM images were obtained using an FEI Tecnai T20 machine operating at $200 \mathrm{kV}$. ICPMS analysis carried out on an Agilent 7700 ICP-MS instrument. The carbon-content in $\mathrm{LiMPO}_{4} / \mathrm{C}$ was 
determined using CE440 CHN/O/S Elemental Analyzer (Exeter Analytical, Inc.). IR spectra were collected using Shimadzu IR affinity spectrophotometer.

For the electrochemical characterization of the $\mathrm{LiFePO}_{4} / \mathrm{C}$ composite, electrodes of $\left(\mathrm{LiFePO}_{4} / \mathrm{C}\right.$ )/carbon/PVDF (80: 10: $\left.10 \mathrm{wt} \%\right)$ were prepared using an aluminium strip as the current collector. Electrochemical tests were carried out using a BioLogic VSP potentiostat in the voltage range $2 \mathrm{~V}$ to $4.2 \mathrm{~V}$ in Swagelok cells with $1 \mathrm{M} \mathrm{LiPF}_{6}$ in $\mathrm{EC} / \mathrm{DMC}(1: 1)$ as electrolyte and lithium foil as counter and reference.

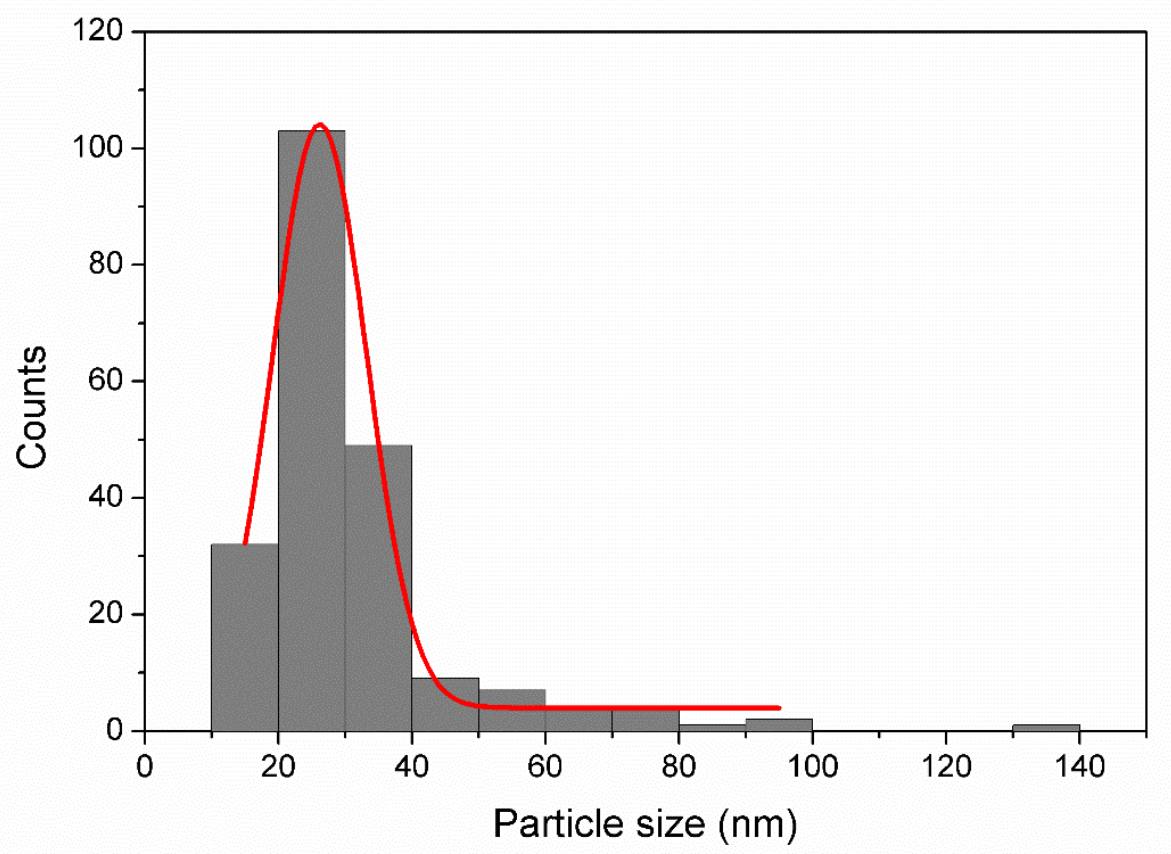

Figure S1. Particle size distribution based on SEM $(\mathrm{N}=210)$ of the $\mathrm{LiPO}_{3}$ phase synthesized at $200{ }^{\circ} \mathrm{C}$ (LP-200). The mean particle size is given as $26( \pm 7) \mathrm{nm}$. 


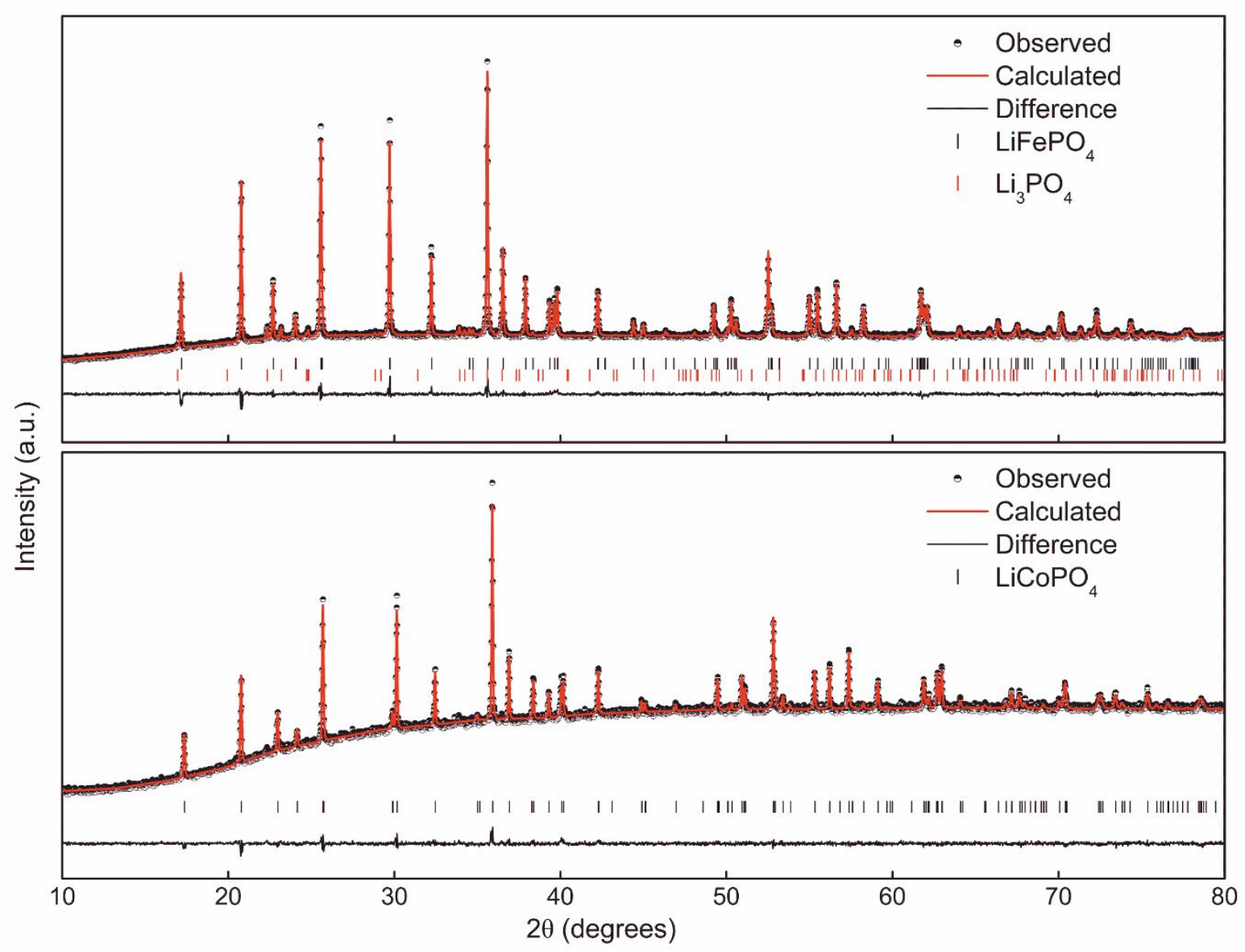

Figure S2. Rietveld fits to XRD data for $\mathrm{LiFePO}_{4}$ and $\mathrm{LiCOPO}_{4}$ at room temperature. $\mathrm{LiFePO}_{4}$ : Space group Pnma, $a=10.3306(1) \AA$, $b=6.0089(1) \AA, c=4.69415(8) \AA$; final fit statistics: $\chi^{2}=2.512 ; R_{w p}=0.0166$, $R_{p}=0.0112$; the sample contains $\mathrm{Li}_{3} \mathrm{PO}_{4}(5.0(5) \mathrm{wt} \%)$ as a secondary phase. $\mathrm{LiCoPO}_{4}$ : Space group Pnma, $a=10.2044(2) \AA$, $b=5.9208(1) \AA, c=4.6994(1) \AA$; final fit statistics: $\chi^{2}=2.048 ; R_{w p}=0.0153, R_{p}=$ 0.0108. Refinements were performed based on full occupancies of the $M$ and $\mathrm{Li}$ sites by $\mathrm{Fe} / \mathrm{Co}$ and $\mathrm{Li}$, respectively (i.e. no antisite defects). 


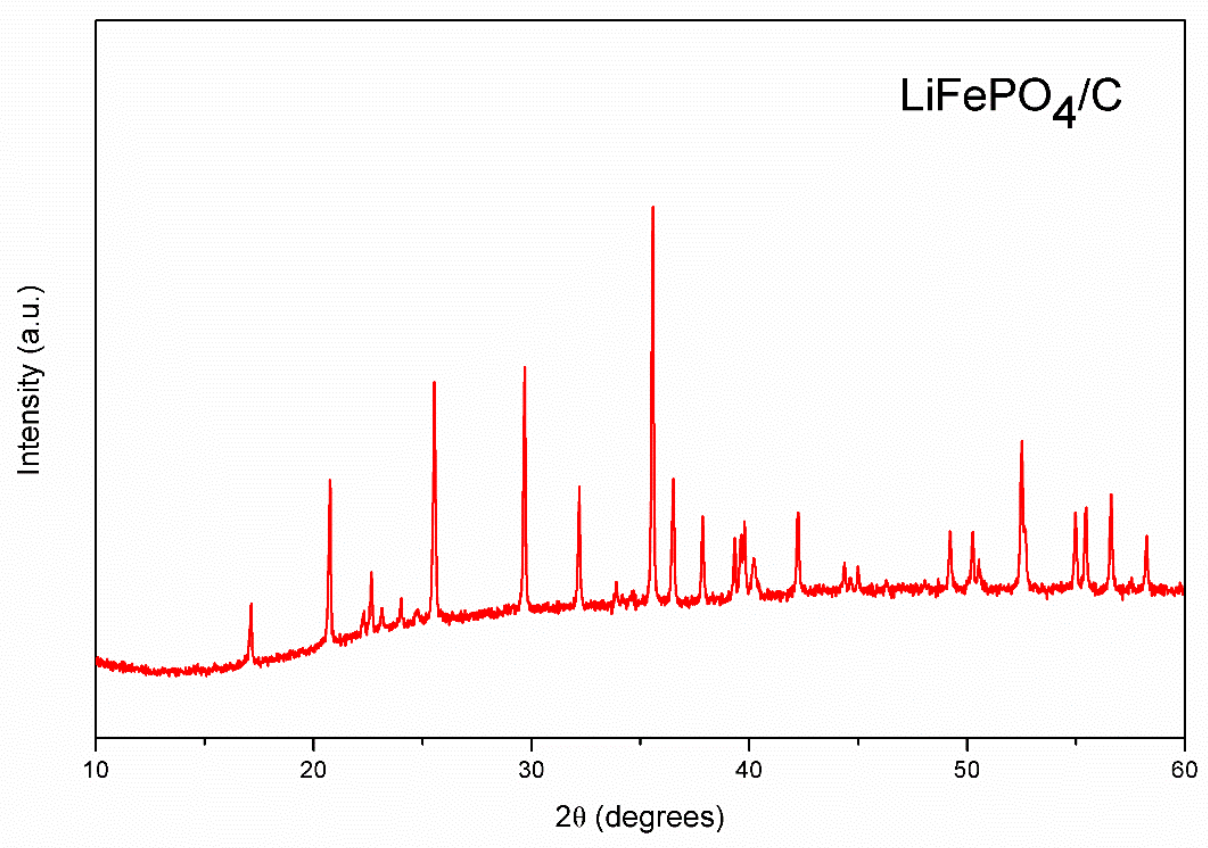

Figure S3. XRD pattern of the $\mathrm{LiFePO}_{4} / \mathrm{C}$ composite

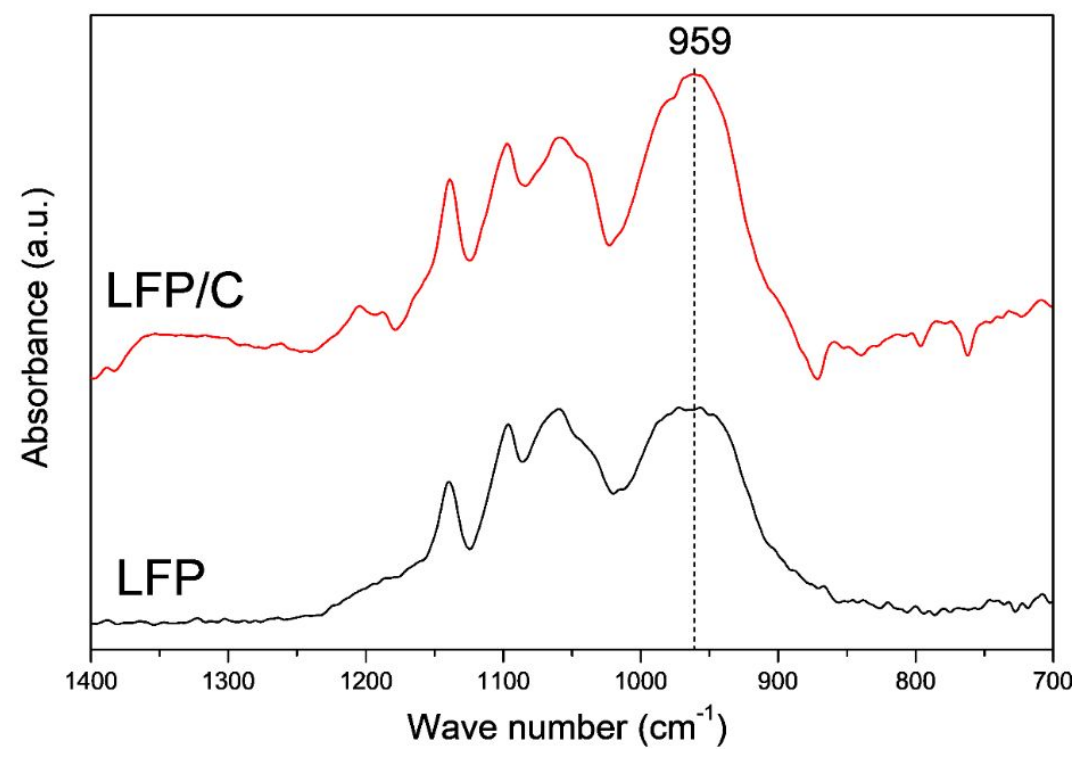

Figure S4. FTIR spectra of $\mathrm{LiFePO}_{4}$ (LFP) and the $\mathrm{LiFePO}_{4} / \mathrm{C}$ composite (LFP/C). 